\title{
New interleukin-15 superagonist (IL-15SA) significantly enhances graft-versus-tumor activity
}

Cavan P. Bailey ${ }^{1}$, Tulin Budak-Alpdogan ${ }^{3}$, Christopher T. Sauter $^{1}$, Michelle M. Panis $^{1}$, Cihangir Buyukgoz ${ }^{1}$, Emily K. Jeng ${ }^{2}$, Hing C. Wong ${ }^{2}$, Neal Flomenberg ${ }^{1}$ and Onder Alpdogan ${ }^{1}$

${ }^{1}$ Department of Medical Oncology, Kimmel Cancer Center, Thomas Jefferson University, Philadelphia, PA, USA

${ }^{2}$ Altor BioScience Corporation, Miramar, FL, USA

${ }^{3}$ Department of Hematology and Oncology, MD Anderson Cancer Center at Cooper, Camden, NJ, USA

Correspondence to: Onder Alpdogan, email: onder.alpdogan@jefferson.edu

Keywords: stem cell transplantation, interleukin-15, cytokine therapy, graft-versus-tumor activity, animal models Received: August 15, $2016 \quad$ Accepted: April 28, $2017 \quad$ Published: May 15, 2017

Copyright: Bailey et al. This is an open-access article distributed under the terms of the Creative Commons Attribution License 3.0 (CC BY 3.0 ), which permits unrestricted use, distribution, and reproduction in any medium, provided the original author and source are credited.

\section{ABSTRACT}

Interleukin-15 (IL-15) is a potent cytokine that increases CD8 ${ }^{+} \mathrm{T}$ and $\mathrm{NK}$ cell numbers and function in experimental models. However, obstacles remain in using IL-15 therapeutically, specifically its low potency and short in vivo half-life. To help overcome this, a new IL-15 superagonist complex comprised of an IL-15N72D mutation and IL-15RaSu/Fc fusion (IL-15SA, also known as ALT-803) was developed. IL-15SA exhibits a significantly longer serum half-life and increased in vivo activity against various tumors. Herein, we evaluated the effects of IL-15SA in recipients of allogeneic hematopoietic stem cell transplantation. Weekly administration of IL-15SA to transplant recipients significantly increased the number of $\mathrm{CDB}^{+} \mathrm{T}$ cells (specifically CD44+ memory/activated phenotype) and NK cells. Intracellular IFN-Y and TNF-a secretion by $\mathrm{CD8}^{+} \mathrm{T}$ cells increased in the IL-15SA-treated group. IL-15SA also upregulated NKG2D expression on $\mathrm{CD8}^{+} \mathrm{T}$ cells. Moreover, IL-15SA enhanced proliferation and cytokine secretion of adoptively transferred CFSE-labeled T cells in syngeneic and allogeneic models by specifically stimulating the slowly proliferative and nonproliferative cells into actively proliferating cells.

We then evaluated IL-15SA's effects on anti-tumor activity against murine mastocytoma (P815) and murine B cell lymphoma (A20). IL-15SA enhanced graftversus-tumor (GVT) activity in these tumors following $T$ cell infusion. Interestingly, IL-15 SA administration provided GVT activity against A20 lymphoma cells in the murine donor leukocyte infusion (DLI) model without increasing graft versus host disease. In conclusion, IL-15SA could be a highly potent T- cell lymphoid growth factor and novel immunotherapeutic agent to complement stem cell transplantation and adoptive immunotherapy.

\section{INTRODUCTION}

IL-15 is a pleiotropic cytokine, which plays various roles in the innate and adaptive immune systems, including the development, activation, homing and survival of immune effector cells, especially NK, NK-T and $\mathrm{CD} 8^{+}$ $\mathrm{T}$ cells [1]. IL-15, a member of the common gamma chain $(\gamma c)$ cytokine family, binds to a receptor complex that consists of IL-15Ra, IL-2R $\beta$ and the $\gamma c$ chain $[2,3]$. Furthermore, IL-15 functions as a key regulator in the development, homeostasis and activity of NK cells $[4,5]$. IL-15 administration to normal mice or overexpression of IL-15 in a transgenic mouse model increases the number and percentage of NK cells in the spleen $[6,7]$, 
the proliferation and survival of NK cells, as well as their cytolytic activity and cytokine secretion. Our laboratory and others have previously shown that IL-15 administration can increase the NK cell number and function in recipients of stem cell transplantation [8-11].

The primary limitations in clinical development of recombinant human IL-15 (rhIL-15) are low production yields in standard mammalian cell expression systems and a short serum half-life $[12,13]$. Moreover, the formation of the IL-15:IL-15R $\alpha$ complex, with both proteins coexpressed in the same cell, can stimulate immune effector cells bearing the IL-2 $\beta \gamma \mathrm{c}$ receptor through a transpresentation mechanism. The studies have shown that IL15/IL-15R $\alpha$ complex increases the affinity of the IL-15 to the IL-2R $\beta$ approximately 150 -fold, when compared with free IL-15 [14]. Various, types of complexes between IL15 and soluble IL-15R $\alpha$ have been generated that exhibit an enhanced biological activity and increased anti-tumor responses in animal models [15-17]

A superagonist mutant of IL-15 (IL-15N72D), which has increased $\mathrm{R} \beta \gamma \mathrm{c}$ binding ability (4-5 fold higher than native IL-15) has been identified for therapeutic usages [18].

Based on these findings, the strong interaction of IL-15N72D and soluble IL-15R $\alpha$ was exploited to create a new IL-15 superagonist complex with the IL-15N72D bound to the IL-15R $\alpha \mathrm{Su} / \mathrm{Fc}$. The soluble fusion protein, IL-15R $\alpha \mathrm{Su} / \mathrm{Fc}$, was created by linking the human IL$15 \mathrm{R} \alpha \mathrm{Su}$ domain with human IgG1 containing the Fc domain. Studies on IL-15:IL-15R $\alpha$ complexes show an advantage of increased intracellular stability of IL$15[19,20]$. Co-expression of both the IL-15N72D and IL-15R $\alpha \mathrm{Su} / \mathrm{Fc}$ proteins resulted in a soluble and stable complex with significantly longer serum half-life and increased biological activity, compared to native IL-15 [21], which was consistent with the results previously shown with other IL-15/IL-15R $\alpha$ complexes [15-17, 22, 23]. As indicated above, this IL-15N72D:IL-15R $\alpha \mathrm{Su} / \mathrm{Fc}$ complex (IL-15SA, or ALT-803) was found to be $>10$ fold more active than free IL-15 in promoting in-vitro proliferation of IL-15-dependent cells [18].

IL-15 SA was previously shown to have potent antitumor activity in syngeneic murine models of multiple myeloma [24]. Here we show the potent effects of IL$15 \mathrm{SA}$ on immune reconstitution and graft-versus-tumor (GVT)/ graft versus leukemia (GVL) activity in recipients of allogeneic hematopoietic stem cell transplantation (HSCT) in murine models.

\section{RESULTS}

\section{Effects of IL-15SA on immune cells following HSCT}

We first evaluated the effects of IL-15SA in T-cell depleted murine BMT models. We used two different MHC-mismatched allotransplant models. We have extensively investigated enhancement of immune reconstitution in our previous studies by cytokines and growth factors $[10,25-28]$. The early reconstitution requires minimum 2-3 weeks post-transplant. Therefore, we administered cytokines either between days 21 and day 28 or days 14-28. We aimed to cover the same period in this study with day 17 and 24 administration schedule.

Lethally irradiated $\mathrm{BALB} / \mathrm{c}$ recipients were transplanted with $\mathrm{T}$ cell depleted (TCD) bone marrow (BM) cells from B6 mice. IL-15SA was administered via intraperitoneal (i.p.) injection in two doses on days 17 and 24 after transplant. Animals were sacrificed on day 28. All recipients had more than $90 \%$ engraftment in the spleens and BMs. There was no significant difference in engraftment and cellularity in the spleens and BMs between IL-15SA and control groups (data not shown). Administration of IL-15SA significantly increased the number of $\mathrm{CD}^{+} \mathrm{T}$ and NK cells, whereas there was no change in $\mathrm{CD}^{+} \mathrm{T}$ cell numbers (Figure 1A). IL-15SA mostly increased $\mathrm{CD} 8+$ memory $\mathrm{T}$ cell population $\left(\mathrm{CD} 44^{\text {high }}\right)$ (data not shown). We observed similar activity in B6CBA $\rightarrow$ CB6F1 transplant model (Figure 1B), in which the animals were treated with the same dose and schedule. IL-15SA also augmented intracellular IFN- $\gamma$ secretion by $\mathrm{CD}^{+}$but not $\mathrm{CD}^{+} \mathrm{T}$ cells in this model (Figure 1C).

We then tested the effects of prolonged administration of IL-15SA on $\mathrm{T}$ cell reconstitution in an allogeneic transplant model. Again, recipients were treated with IL-15SA i.p. on days 28, 35 and 42 after MHC-mismatched HSCT (B6 ${ }^{\circledR}$ B6D2F1). We found that IL-15SA administration increased the $\mathrm{CD} 8^{+}$memory/ effector $\mathrm{T}$ cell population, but did not show any activity on both $\mathrm{CD}^{+}$memory and naïve $\mathrm{T}$ cell populations. Interestingly, $\mathrm{CD}^{+}$naïve $\mathrm{T}$ cells also remained unaffected in both IL-15SA treated and untreated groups (Figure 2A). We also evaluated other activation markers on the lymphocytes. Interestingly, we found a 10 -fold increase in $\mathrm{NKG} 2 \mathrm{D}$ expression on $\mathrm{CD}^{+} \mathrm{T}$ cells, suggesting that some $\mathrm{CD}^{+} \mathrm{T}$ cells turn into effector/cytotoxic lymphocytes with innate-like phenotype (Figure 2B) after exposure to IL-15SA. These effects of IL-15SA on immune cells after HSCT are similar to previously observed changes in preclinical studies [29]. We did not find a significant change of surface CD107a expression on both $\mathrm{CD}^{+}$or $\mathrm{CD}^{+} \mathrm{T}$ cells, which is a marker of degranulation of the cytolytic perforin/granzyme pathway against the tumors (data not shown).

We then did another experiment to test the duration of IL-15 SA effects in our models. B6D2F1 recipients were lethally irradiated and transplanted with TCD B6 BM cells. The recipients were treated with IL-15 SA on days 35, 42 and day 49 and harvested on day 63 after allogeneic HSCT. observed similar spleen and 
CD4+T cell counts, but CD8+T cells T cells significantly increased two weeks after the last dose of IL-15 SA (Figure 2C). We concluded that the effects of IL-15 SA on immune reconstitution last at least two weeks after the administration.

We further examined the effects of IL-15SA on allogeneic proliferating cells in murine models. CFSE (carboxyfluorescein succinimidyl ester) labeled splenocytes from B6 mice were transferred into lethally irradiated B6D2F1 recipient mice. IL-15SA was given on the same day after splenocytes infusion. All animals were sacrificed three days after splenocyte infusion. IL15SA treatment specifically promoted proliferation of slow-proliferating $\mathrm{CD}^{+} \mathrm{T}$ cells in conjunction with robust IFN- $\gamma$ and TNF- $\alpha$ secretion, in allogeneic recipients of CFSE labeled-T-cell infusion. However, there was no effect of IL-15SA on CD4 ${ }^{+} \mathrm{T}$ cell proliferation (Figure 3A). Interestingly, we have not seen a significant increase in TNF-a secretion by $\mathrm{CD}^{+} \mathrm{T}$ cells following IL-15 administration in previous experiments [28], suggesting that IL-15SA is more potent than native IL15 for inducing cytokine secretion in $\mathrm{CD}^{+} \mathrm{T}$ cells in vivo. We then evaluated IL-15SA activity in syngeneic recipients of CFSE labeled T-cell infusion. Again, we found that IL-15SA increased proliferation and IFN- $\gamma$ secretion in adoptively transferred $\mathrm{CD}^{+} \mathrm{T}$ cells, but it did not increase their TNF-a secretion (Figure 3B). These results further suggest that additional stimulatory signals, such as TCR-MHC engagement in the allogeneic rather than the syngeneic adoptive $\mathrm{T}$ cell transfer setting, are potentially necessary to induce TNF- $\alpha$ secretion by IL15SA stimulation.

\section{Antitumor activity of IL-15SA in murine tumor models}

Next, we tested the anti-tumor activity of IL-15SA in two different tumor models; murine mastocytoma (P815) and murine B cell lymphoma (A20). First, we evaluated anti-tumor activity of IL-15SA in the P815 model, without $\mathrm{T}$ cell administration. We could not detect any significant graft-versus-tumor (GVT) activity in recipients of P815 in parent-F1 model when IL-15SA was administered without the $\mathrm{T}$ cell infusion (data not shown). When we infused a small amount of $\mathrm{T}$ cells into the B6 ${ }^{\circledR} \mathrm{B} 6 \mathrm{D} 2 \mathrm{~F} 1$ model, we found that IL-15SA administration significantly enhanced anti-tumor activity against P815 tumor cells with two different T cell doses; $5 \times 10^{4}$ and $1 \times 10^{5}$ cells, respectively (Figure 4A and $4 \mathrm{~B}$ ). We did not observe any significant signs of GVHD in these experiments. Only two animals had a GVHD score of 1 because of minimal weight loss, which might be related tumor growth (in Figure 4A and no sign of GVHD in 4B). All animals died from tumor development with hind leg paralysis or presence of tumor metastasis in the autopsy. Therefore, IL-15SA administered with $\mathrm{T}$ cell infusion in the P815 model, provided a limited benefit to the tumor-bearing mice, compared to the control group.

In the A20 murine lymphoma model, we evaluated anti-lymphoma activity against A20 cells in recipients of allogeneic HSCT, with or without T cell infusion. A20 cells were kindly provided by Dr. Marcel van den Brink's laboratory (Memorial Sloan-Kettering Cancer Center, New York, NY), expressing triple gene construct with luciferase activity that allowed us to detect tumor growth with

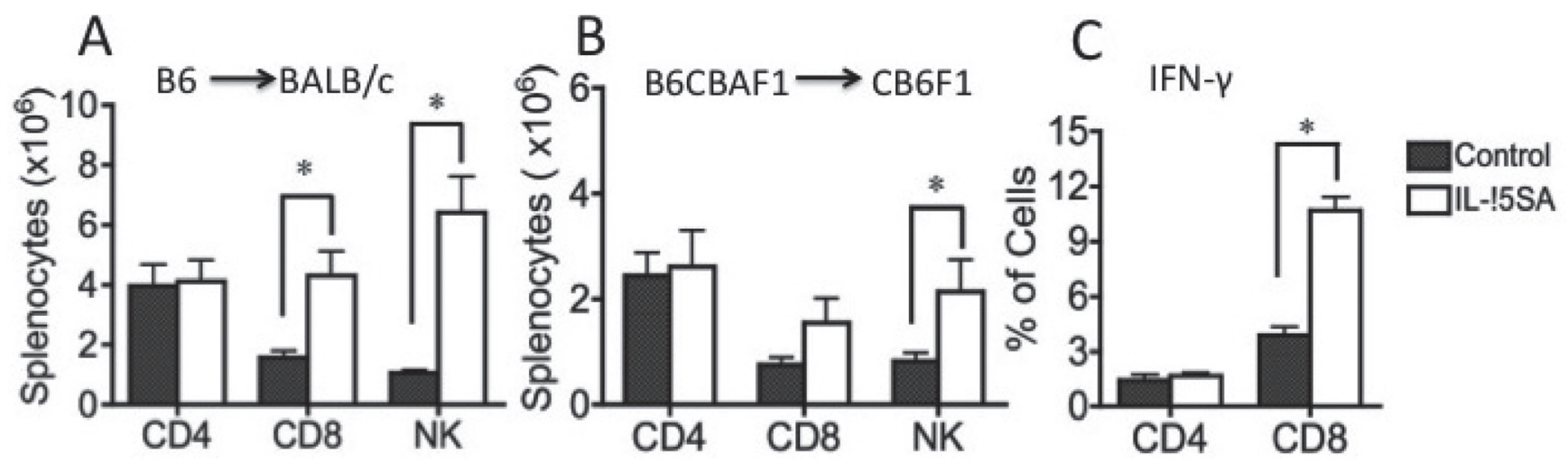

Figure 1: IL-15SA administration increases $\mathrm{CD8}^{+} \mathbf{T}$ and $\mathrm{NK}$ cell numbers after transplantation. (A) Lethally irradiated (11Gy) Balb/c recipients were transplanted with $5 \times 10^{6} \mathrm{~T}$-cell depleted (TCD) bone marrow (BM) cells from B6 mice. IL-15SA was administered via IP injection at $1 \mu \mathrm{g}$ per mouse in two doses on days +17 and +24 . Mice were sacrificed at day 28 after transplant, and spleens, thymi and BM were harvested. Single cell suspensions were prepared and stained with anti-H2Kd, -CD3, -CD4, -CD8, -Gr-1, -NK1.1, and -B220 antibodies, and analyzed with a flow cytometer. Each group contains 5 mice. Splenic numbers of CD4+ T, CD8+ T, and NK cells, are shown. ${ }^{*} P<0.05$. Figure $1 \mathrm{~B}$ and $1 \mathrm{C}$. Lethally irradiated (12Gy) CB6F1 recipients were transplanted with $5 \mathrm{x} 10^{6} \mathrm{~T}-\mathrm{cell}$ depleted (TCD) bone marrow (BM) cells from B6CBA mice. IL-15 super agonist was administered via IP injection at $1 \mu \mathrm{g}$ per mouse in two doses on days 17 and 24. Mice were sacrificed at day 28 after transplant, and spleens, thymi and BM were harvested. After preparation of single cell suspensions, cells were stained with anti-H2Kd, -CD4, -CD8 (B). Some splenocytes are also incubated as described for intracellular staining, then harvested and stained with anti-H2Kd, -CD4, -CD8 and IFN- $\gamma$ antibodies and analyzed with a flow cytometer (C). Each group contains 5 mice. ${ }^{*} P<0.05$ 
bioluminescence imaging (BLI). First, we developed an A20 murine tumor model and found that infusion of $1 \times 10^{5}$ donor $\mathrm{T}$ cells provided a significant anti-tumor activity and survival benefit in the B6CBAF1 $\rightarrow$ CB6F1 (MHCmismatched) model. Thus, we lethally irradiated CB6F1 mice and transplanted B6CBAF1 BM along with $1 \times 10^{5} \mathrm{~T}$ cells. All animals received A20 tumor cells on the same day as the BM transplant. We found that all animals survived in the IL-15SA-treated group, which is statistically significant compared to the control group (Figure 4C).
We then explored anti-lymphoma/leukemia activity of IL-15SA in allogeneic HSCT recipients, without any T cell infusion in the A20 model. Same dose and route of IL15SA were used as previously described. Tumor growth was determined by intensity of photon measurements using IVIS bioluminescence system (Figure 5A, 5B). Although we observed that two administrations of IL15SA could provide a delay of A20 cell growth in vivo, the delayed tumor growth by IL-15SA administration did not result in survival difference between the IL-15SA and
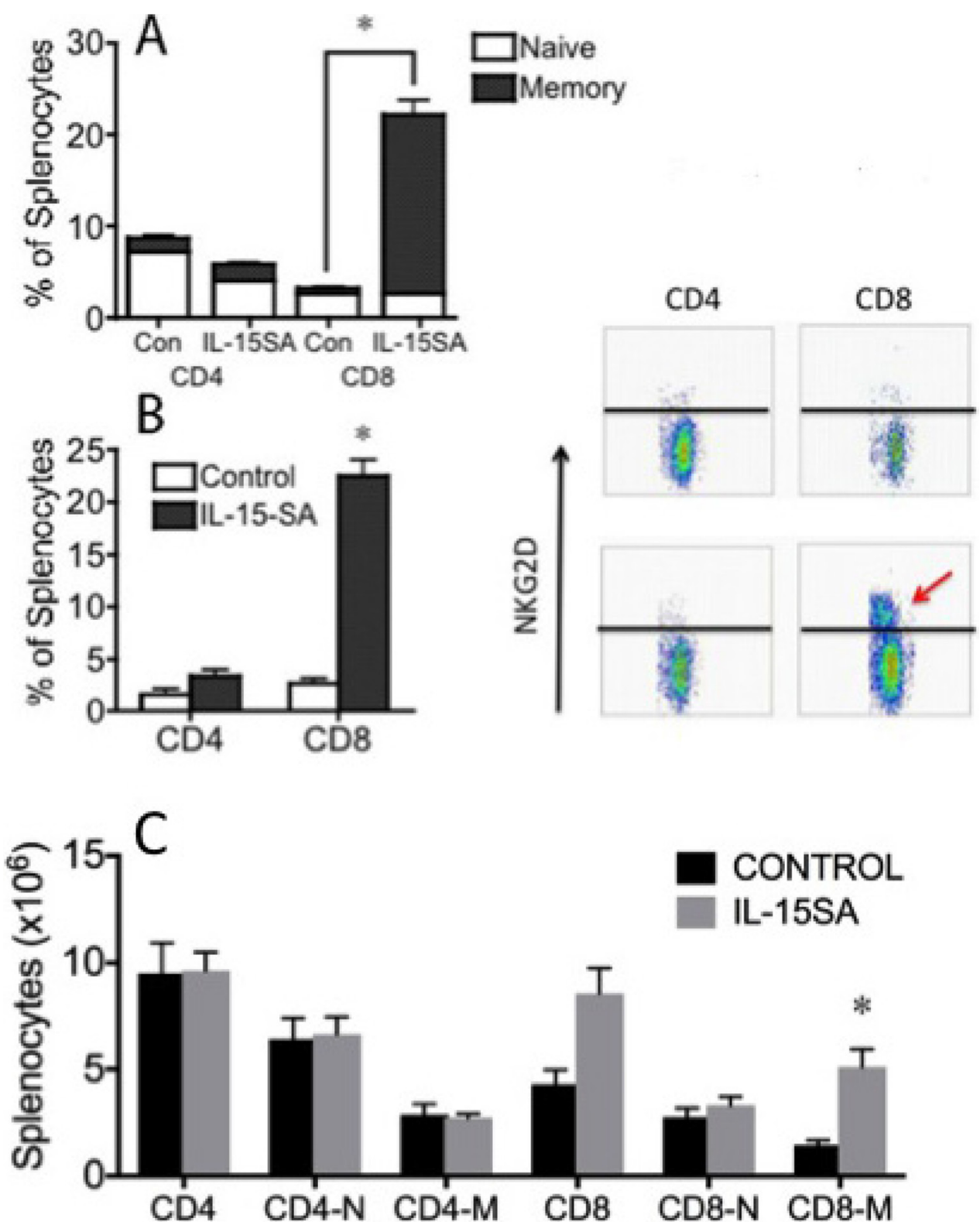

Figure 2: IL-15SA administration increases $\mathrm{CD8}^{+} \mathrm{CD}^{+} 4^{+}$and $\mathrm{CD8}^{+} \mathrm{NKG}^{+}$effector/memory $\mathrm{T}$ cells. Lethally irradiated (12Gy) B6D2F1 recipients were transplanted with $5 \times 10^{6}$ T-cell depleted (TCD) bone marrow (BM) cells from B6 mice. IL-15SA was administered via IP injection at $2.5 \mu \mathrm{g}$ per mouse on days 28, 35 and 42. Mice were sacrificed at day 49 after transplant, and spleens were harvested. Single cell suspensions were prepared and stained with anti-H2Kd, -CD3, -CD4, -CD8, -CD44 and -NKG2D antibodies. Cells were acquired and analyzed with a flow cytometer (A and B). IL-15SA was administered via IP injection at $2.5 \mu \mathrm{g}$ per mouse on days 35 , 42 and 49. Mice were sacrificed at day 63 after transplant, and spleens were harvested. Single cell suspensions were prepared and stained with anti-H2Kd, -CD3, -CD4, -CD8, and -CD44 (C). 
the control group (Figure 5C). Interestingly, IL-15SA is still successful in generating anti-tumor activity against A20 lymphoma cells without a T cell infusion.

Taken together, the results of these experiments indicate that IL-15SA significantly increases the antilymphoma /leukemia activity in murine HSCT by effectively promoting the effector/memory $\mathrm{CD}^{+} \mathrm{T}$ and NK cell expansion and potently enhancing their effector functions.

\section{IL-15SA enhances anti-tumor activity with donor leukocyte infusion (DLI)}

DLI has been developed as a strategy for management of relapse by increasing graft-versus-tumor effects after allogeneic HSCT [30]. DLI is used in nearly all malignant hematological diseases for which allogeneic HSCT is performed. However, the response to DLI varies with respect to the methods of cell collection, timing,

A

$\mathrm{B} 6 \rightarrow \mathrm{B} 6 \mathrm{D} 2 \mathrm{~F} 1$

CD4
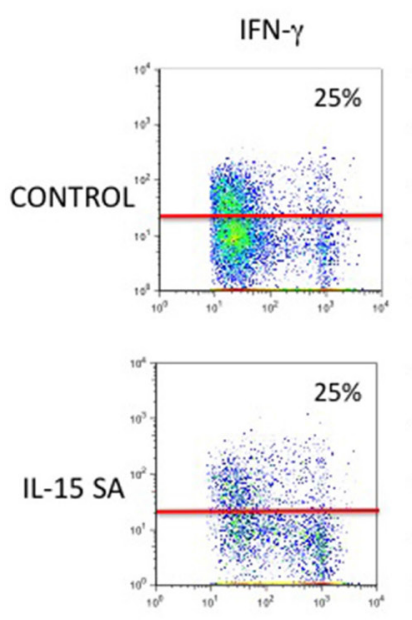

TNF- $\alpha$
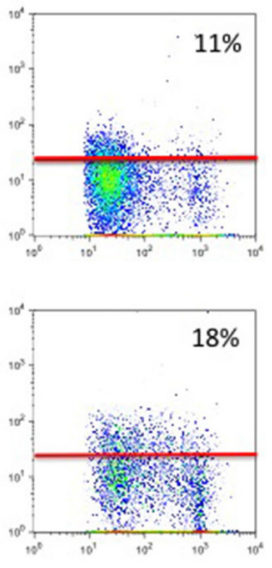

\section{CFSE}

\section{$\mathrm{CD} 8$}
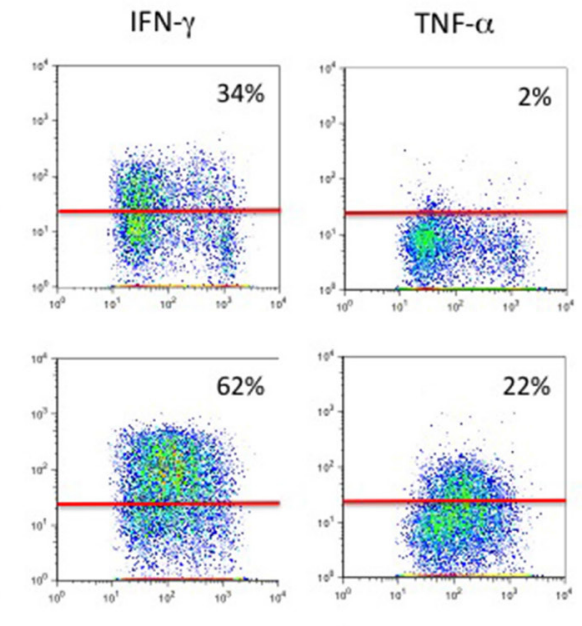

$\longrightarrow$
B
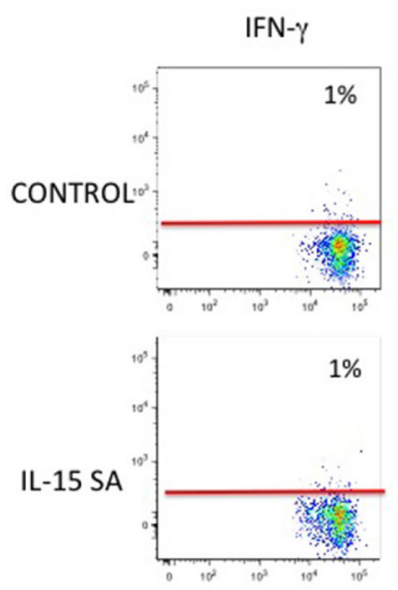

B6 (Ly5.1) $\rightarrow$ B6

CD4

TNF- $\alpha$
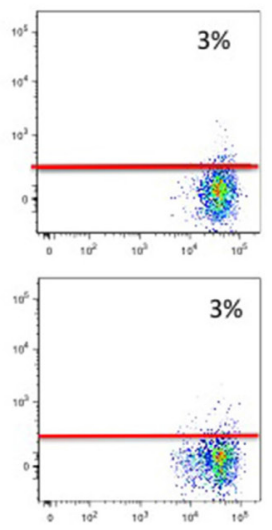

CD8
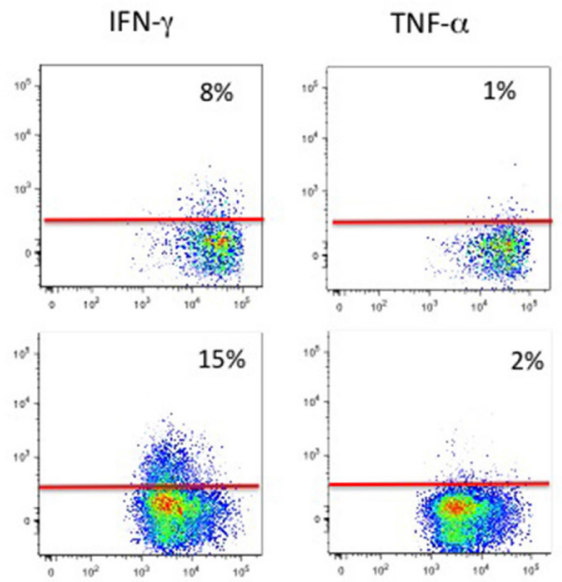

Figure 3: IL-15SA administration increases cytokine secretion and proliferation of $\mathrm{CD8}^{+} \mathrm{T}$ cells in recipients of CFSE labeled T cells. Lethally irradiated (1300 cGy) either B6D2F1 (A) or B6(Ly5.1) mice (B) were transplanted with CFSE labeled B6 splenocytes $\left(30 \times 10^{6}\right)$ at day 0 and given either IL-15SA or a vehicle control (Day 0 post infusion). Mice were sacrificed on day 3 after CFSE labeled leukocyte infusion and splenocytes were stained with anti-CD4, -CD8, CD45.1 and -H2Kd antibodies. Cells then were analyzed by flow cytometry. Intracellular staining with anti-IFN- $\gamma$ and anti-TNF- $\alpha$ antibodies after PMA and ionomycin stimulation was performed. Red line indicates boundary of isotypic control and arrows indicate increase in IFN- $\gamma$ secretion in the slow proliferating CD $8^{+}$ T cells. 
cell dose infused, and even cell sub-type used (reviewed in [31]). To enhance the efficacy of DLI infusion would improve the outcome the patients who relapse after allogeneic HSCT. Therefore, we studied whether IL15SA can be used to enhance the efficacy of DLI in animal models. To achieve this, we first developed a DLI model with recipients of allogeneic HSCT. Lethally irradiated CB6F1 recipients were transplanted with T-cell-depleted B6 BM cells. A20 murine lymphoma cells were infused at the day of transplant. Purified T cells were infused after tumor growth in recipients of allo HSCT. We found that a moderate dose of $\mathrm{T}$ cell infusion $\left(2.5 \times 10^{5}\right.$ cells $)$ provides GVL activity after tumor development in recipients of allo-HSCT (data not shown). The IL-15SA-treated group exhibited a better survival and less weight loss after transplant compared to the untreated group (Figure 6A and Figure 6B). We also monitored tumor growth in all animals with BLI. We found that IL-15SA administration resulted in significantly decreased photon intensity by BLI, which suggests IL-15SA was able to inhibit tumor growth (Figure $6 \mathrm{C}$ and 6D). $20 \%$ of recipients in the IL-15 SA group had score of 1, related to weight loss and mobility. No animals died from GVHD in the IL-15SA group. 30\% animals had a low GVHD score between 1-2 in the control-DLI group. Only one animal died from GVHD in the control group. All other animals died from progression of leukemia/ lymphoma (they have either a significant tumor growth or hind leg paralysis, which is a sign of tumor growth). We concluded that we did not observe an increase in GVHD score and weight loss in IL-15SA-treated group compared to the control group (Figure 6B) suggesting that IL-15SA did not promote GVHD in this murine HSCT model after a low dose T-cell infusion. Thus, IL-15SA administration after allogeneic HSCT enhances GVL/lymphoma activity without aggravating GVHD in the low-dose DLI murine models.

\section{DISCUSSION}

We have previously shown that IL-15 enhances anti-tumor activity in recipients of allogeneic and haploidentical HSCT [10, 28]. IL-15 half-life is roughly 1 hour after administration and must be administered daily for treatment [15]. The long-term effects of recombinant human IL-15 (rhIL-15) have been studied in non-human primates, demonstrating that daily administration of IL-15 for 8-14 days resulted in lymphocytosis and leukocytosis, and white blood cell count returned to normal after discontinuation of IL-15 on day 28 in these studies [32]. Immunological parameters also returned to baseline on day 28 in the same studies. Due to the limitations with the short half-life and daily administration of IL-15, alternative dosing strategies of IL-15 require further assessment in the therapeutic setting.

Recently, Conlaon et al. reported that recombinant human interleukin-15 administration resulted in NK and $\mathrm{CD}^{+} \mathrm{T}$ cells redistribution, proliferation, activation of $\mathrm{NK}$ and $\mathrm{CD}^{+} \mathrm{T}$ cells and enhanced inflammatory cytokine production after daily bolus infusion [33]. Authors also mentioned that alternative dosing strategies have been studied to decrease the toxicity of cytokine. IL-15 SA (ALT-803) with a better safety profile and a
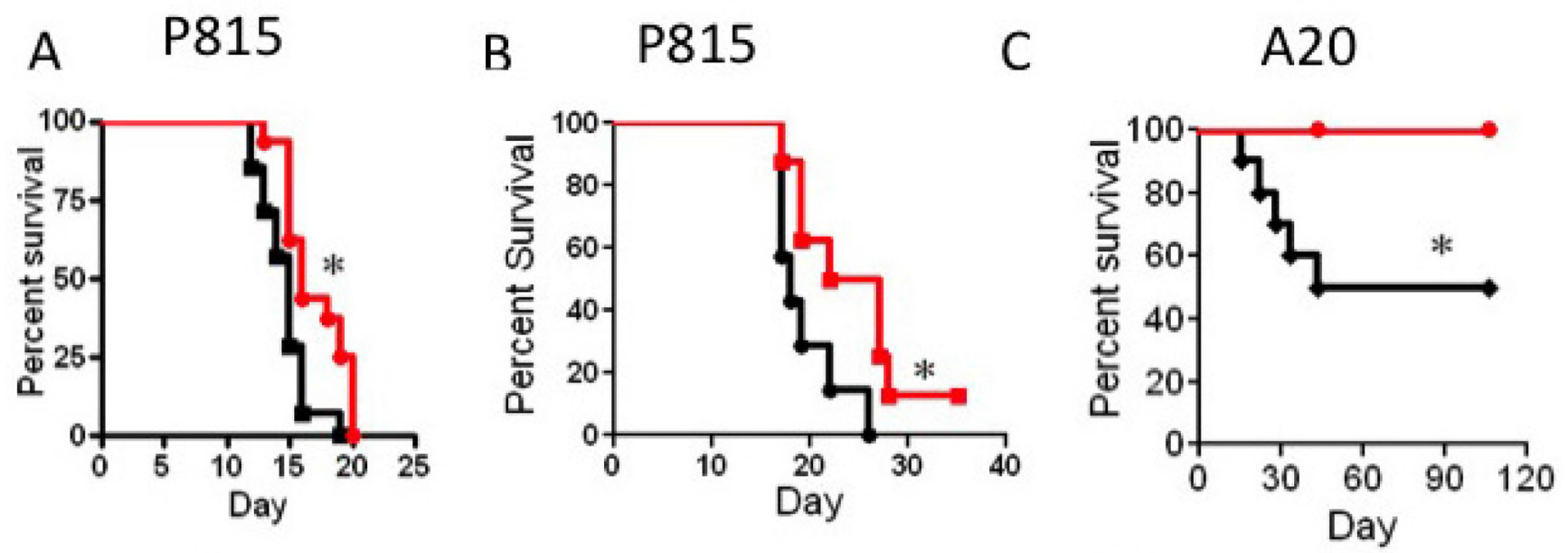

Figure 4: IL-15SA administration increases GVT activity after transplant. (A and B) Lethally irradiated (13Gy) B6D2F1 recipients were transplanted with $5 \times 10^{6}$ T-cell depleted $(\mathrm{TCD})$ bone marrow $(\mathrm{BM})$ cells from $\mathrm{B} 6$ mice. All recipients also received $1 \times$ $10^{4} \mathrm{P} 815$ cells on the day of transplantation along with $5 \times 10^{4}(4 \mathrm{~A})$ or $1 \times 10^{5}(4 \mathrm{~B})$ purified B6 T-cells. IL-15SA was administered via IP injection at $2.5 \mu \mathrm{g}$ per mouse in two doses on days 7 and 14. Kaplan Mayer curves for this transplant modality are depicted as follows; vehicle control (black line) and IL-15 super agonist (red line). ${ }^{*}=p<0.05$, and each group had 15 mice. (C) Lethally irradiated (13Gy) CB6F1 recipients were transplanted with $5 \times 10^{6} \mathrm{~T}$-cell depleted (TCD) bone marrow (BM) cells from B6 mice. All recipients also received $5 \times 10^{5} \mathrm{~A} 20$ cells on the day of transplantation along with $1 \times 10^{5}$ purified B6 T-cells. IL-15SA was administered via IP injection at $2.5 \mu \mathrm{g}$ per mouse in two doses on days 7 and 14. Kaplan Mayer curves for this transplant modality are depicted as follows; vehicle control (black line) and IL-15 super agonist (red line). ${ }^{*}=p<0.05$, and each group had 10 mice. 
longer half-life will potentially provide an advantage in clinical use.

We have shown in this study that a new IL15 superagonist complex, IL-15SA, is a potent immunotherapeutic agent for stimulating $\mathrm{NK}$ and $\mathrm{CD} 8^{+} \mathrm{T}$ cells in recipients of allogeneic HSCT in murine models. IL-15SA promoted the expansion of $\mathrm{CD}^{+}$memory $\mathrm{T}$ cells and NK cells but not $\mathrm{CD}^{+} \mathrm{T}$ cells. IL-15SA also significantly increased the levels of NKG2D expression on $\mathrm{CD}^{+} \mathrm{T}$ cells. NKG2D, an activating receptor of innate immune cells, is mainly expressed on the surface of NK cells, $\gamma \delta \mathrm{T}$ cells, and activated CD $8^{+} \mathrm{T}$ cells. The NKG2D receptor plays a pivotal role in both innate and adaptive immunity against tumorigenesis and tumor surveillance $[34,35]$. In the previous studies, IL-15SA induced memory $\mathrm{CD}^{+} \mathrm{T}$ cells to proliferate, upregulate receptors involved in innate immunity, secrete IFN- $\gamma$ and acquire the ability to kill malignant cells in the absence of antigenic stimulation in murine models of multiple myeloma [24]

The studies described in this paper demonstrate for the first time that IL-15SA may have similar effects on the immune cells in the HSCT setting. Thus, it is conceivable that $\mathrm{CD} 8^{+} \mathrm{T}$ cells with high NKG2D expression (i.e.,
NKT cells) are induced by IL-15SA, and contributed to potent anti-A20 tumor activity in HSCT. This is consistent with the results from a recent report that showed NKG2D expression on $\mathrm{CD} 8^{+} \mathrm{T}$ cells is related to mediating GVHD and GVT by promoting the survival and cytotoxic function of $\mathrm{CD}^{+} \mathrm{T}$ cells [36]. NKG2D blockade was shown to attenuate GVHD, while allowing $\mathrm{CD} 8^{+} \mathrm{T}$ cells to regain anti-tumor activity. Besides functioning as an activating receptor for cell-mediated cytotoxicity of T-NK cells against tumors, NKG2D has also been suggested to act as a receptor to recruit T-NK cells to the tumor sites in which tumor cells overexpress stress-inducible NKG2D ligands [37].

In this study, we continue to observe the phenomenon of the IL-15SA not significantly promoting $\mathrm{CD}^{+} \mathrm{T}$ cell proliferation and activation. We have shown that IL-15 SA increased CD8+ $\mathrm{T}$ cell proliferation and IFN-g and TNF-a secretion from CD8+ T cells in recipients of allogeneic CFSE-labeled splenocyte infusion. Increased TNF-a secretion in allogeneic model might be related toan increase in $\mathrm{T}$ cells that may not be detectable in syngeneic model. These data may suggest that IL-15 SA may aggravate GVHD in allogeneic, though we have
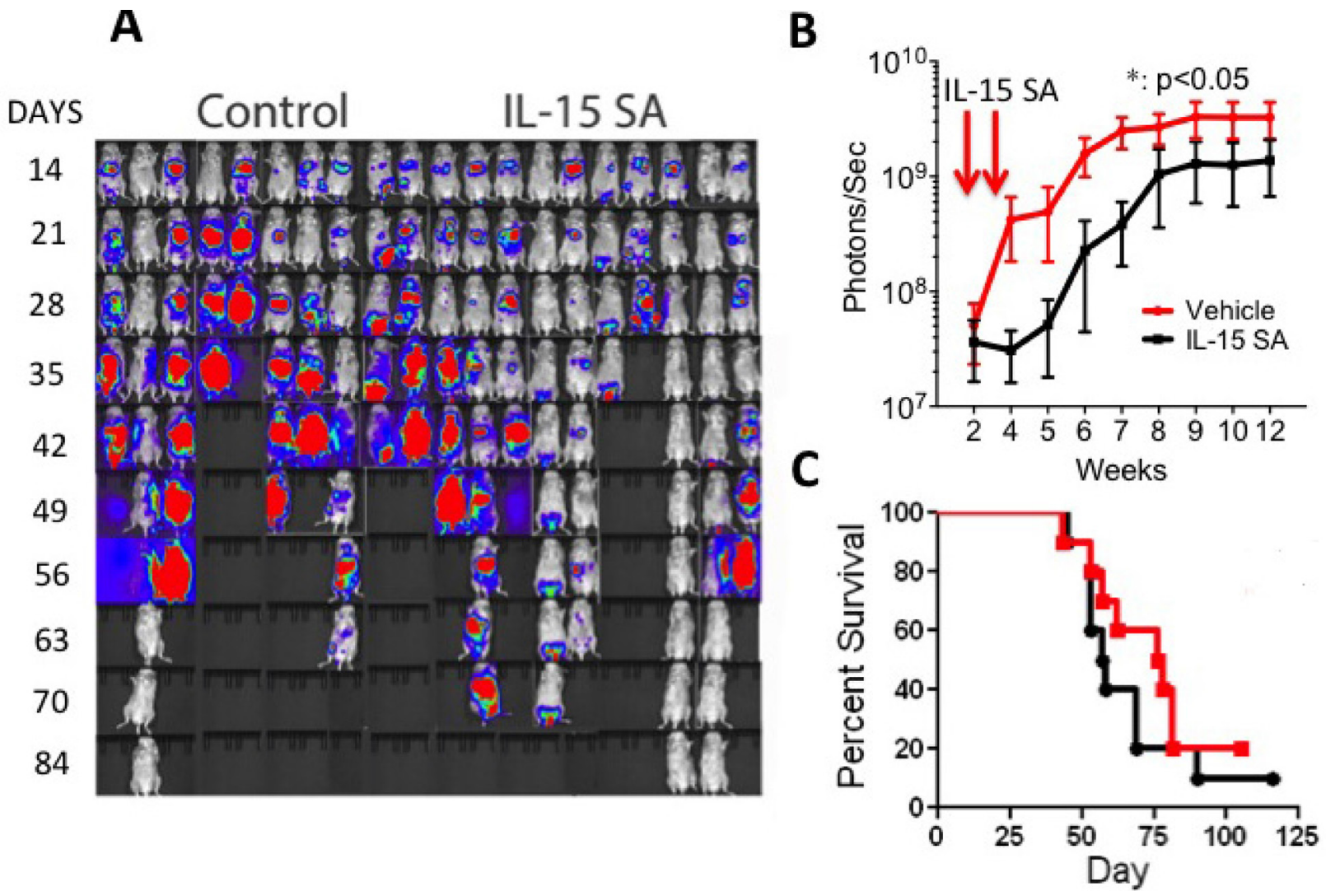

Figure 5: IL-15SA delays A20 lymphoma cells growth in recipients of HSCT. Lethally irradiated (12Gy) CB6F1 recipients were transplanted with $5 \times 10^{6} \mathrm{~T}$-cell depleted (TCD) bone marrow (BM) cells from B6 mice. All recipients also received $5 \times 10^{5} \mathrm{~A} 20$ cells on the day of transplantation along without T cell infusion. IL-15SA was administered via IP injection at $2.5 \mu \mathrm{g}$ per mouse in two doses on days +7 , and +14 . In vivo luminescent imaging of experiment is shown in (A) Mice were injected with luciferin at $3.75 \mathrm{mg}$ per mouse, allowed to incubate for 8 mins, and then imaged for 3 mins. Control group on the left, IL-15SA on the right. Photon intensity is calculated and shown in $(\mathbf{B}) *=p<0.05$, and each group had 10 mice. 
not seen this in our low dose T cell models Interestingly, IL-15SA increases IFN-g and TNF-a secretion from slow proliferative CD8 $(+) \mathrm{T}$ cells that may resemble the more homeostatic expansion of $\mathrm{T}$ cell in the lymphopenic environment $[10,25,28]$

We have previously shown that IL-15 administration after allogeneic HSCT may enhance the occurrence of GVHD in T cell-repleted models, but it does not have effect on GVHD after TCD-BMT [10]. Interestingly, IL15 did not increase GVHD in recipients of a very low dose $\mathrm{T}$ cell infusion [28]. Using the same model in this study, we also found that IL-15SA did not increase the occurrence of GVHD and resulted in improved survival of haploidentical HSCT recipients of tumor bearing mice.
Herein, we demonstrated that IL-15SA increased NK cell numbers in recipients of haploidentical HSCT. IL-15SA has also been shown to potently activate the cytotoxicity of NK cells [38]. NK cell alloreactivity in recipients of mismatched HSCT may suppress development of GVHD by decreasing host-derived antigen presenting cells [39]. Thus, it is conceivable that the increase of NK cell numbers and the enhancement of their cytotoxicity by IL-15SA administration in haploidentical HSCT not only contribute to the GVT but also decrease host-derived antigen presenting cells. The decrease in host-derived antigen presenting cells reduces the activation of hostspecific $\mathrm{CD}^{+}$effector $\mathrm{T}$ cells which are responsible for GVHD. However, NK cell-associated GVT activity was
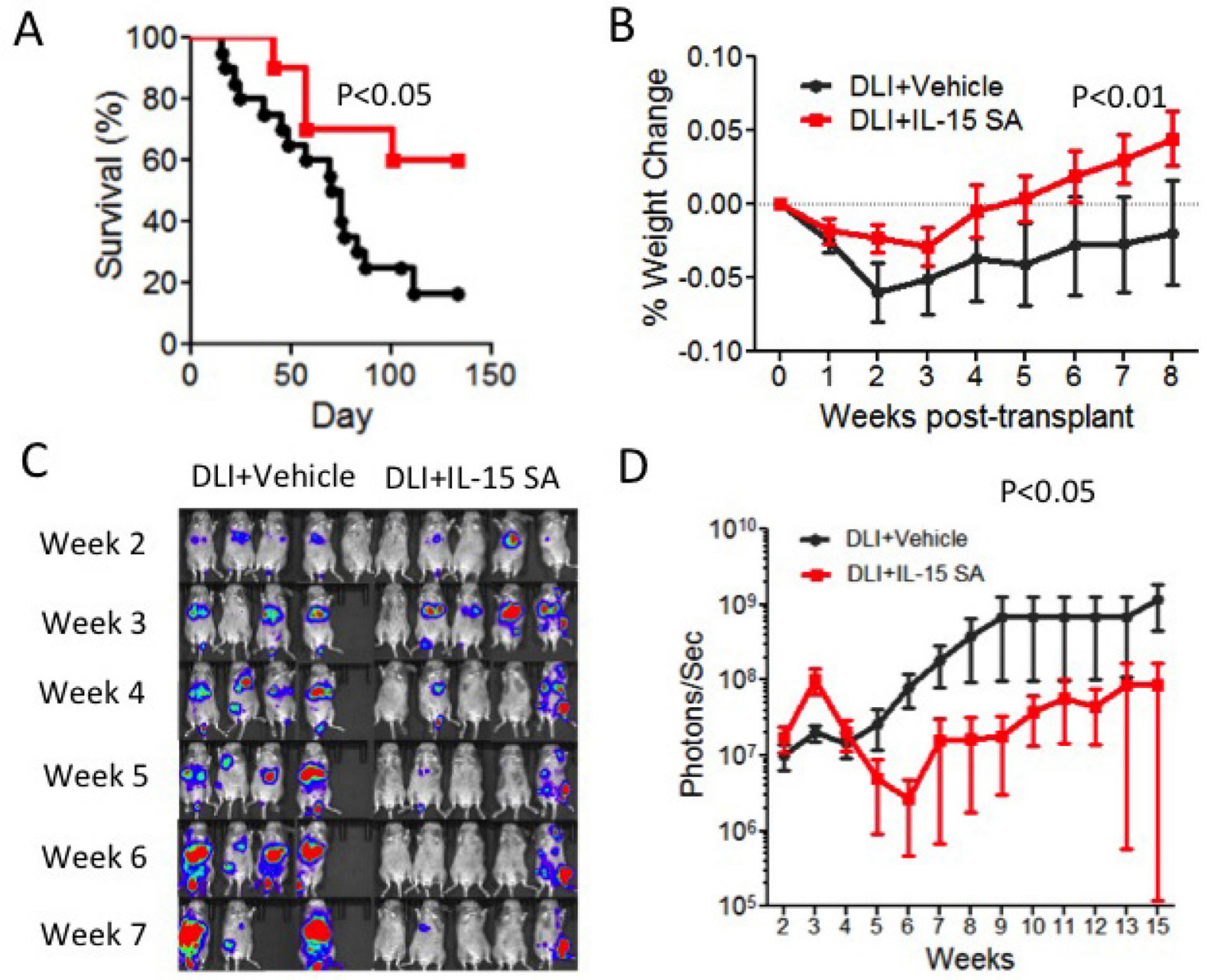

Figure 6: IL-15SA increases anti-tumor activity after DLI infusion in murine leukemia/lymphoma model. Lethally irradiated (12Gy) CB6F1 recipients were transplanted with $5 \times 10^{6}$ T-cell depleted (TCD) bone marrow (BM) cells from B6 mice. All recipients also received $5 \times 10^{5}$ A20-TGL $\left(\mathrm{H} 2 \mathrm{~K}^{\mathrm{d}}\right)$ lymphoma cells with triple fusion gene carrying luciferase activity on the day of transplantation. The recipients of transplant received none or $2.5 \times 10^{5} \mathrm{~B} 6 \mathrm{~T}$-cells isolated via $\mathrm{CD}^{+}$magnetic separation on day 14 after transplant. Animals received either intraperitoneal (IP) injections of IL-15 SA (1ug per mouse) or control on days 17 and 24 after transplant. Survival and weight curves of the groups are depicted as (A and B) $(N=10-20)$. Serial bioluminescence images are obtained by IVIS machine in varying time points as show. A20-TGL cells express Luciferase protein allowing in vivo bioluminescent imaging; mice were injected with $3.75 \mathrm{mg}$ Luciferin, incubated for $5 \mathrm{mins}$, and imaged for $3 \mathrm{mins}$. Serial bioluminescence images are obtained by IVIS machine in varying time points as show $(\mathbf{C})$ representative of independent of two experiments). Control group on the left, IL-15 SA group on the right. Total flux (photons/sec) was measured for each mouse at each time point and plotted as a curve (D). 
apparently not strong enough to overcome the A20 tumor growth and improve the overall survival of the A20 lymphoma bearing recipient without $\mathrm{T}$ cell infusion preor post-transplant. Only a low dose of T cell infusion was shown to be required to provide survival advantage in the IL-15SA treatment group. This is likely the result of IL15SA's unique capabilities of promoting the expansion of $\mathrm{CD}^{+}$memory $\mathrm{T}$ cells and enhancing their effector functions.

DLI has been developed as a strategy for relapsemanagement by increasing GVT effects after allogeneic HSCT [30]. DLI is used to treat most malignant hematologic diseases in recipients with relapsed disease after HSCT. The general response rate is less than $30 \%$ in patients with acute leukemia and is not durable [31]. Collins et al. has found the response rate to DLI to be less than $20 \%$ in acute leukemia patients [40]. In recent years, new methods have been developed to enhance the efficacy of DLI for the treatment of relapsed or persistent hematological malignancies after allogeneic HSCT [41]. Enhancing donor leukocyte activity with various cytokines has been explored. Interleukin-2 treatment after DLI in patients with relapsed leukemia after allo HSCT did not provide beneficial outcome, and increased the occurrence of GVHD [42]. Interleukin-15 has never been used following DLI in humans or murine transplant models.

The activity of DLI in murine models is affected by donor/host MHC Ag disparity, DLI dose, and tumor type. We developed the DLI model against the A20 murine lymphoma model system. In this model, we could detect a significant anti-tumor activity of DLI with a combination of IL-15 SA. We think that a major differences in our models and published data are $\mathrm{T}$ cell dose and the timing of tumor infusion. $2-5 \times 10^{7}$ splenocytes were infused in the previous DLI studies in murine models [43-46]. T cell dose in those studies was approximately 1-2 log higher than the dose that was used in our studies $\left(2.5 \times 10^{5}\right)$. As a result of that, the occurrence of GVHD diminished in this study. The timing of the tumor/leukemia cell infusion is also different in our study. We tried to mimic the clinical scenario for DLI infusion. The therapeutic DLI infusion is given after leukemia recurrence post-transplant in the patients with allogeneic HSCT. We aimed to test the efficacy of DLI after tumor development. Therefore, tumor cells were infused on the day of the transplant and the most of the recipients were detectable tumor by BLI at day 14 after HSCT. When we tested the timing of DLI, we observed that infusion at day 21 might be late to overcome the tumor development with a low dose $\mathrm{T}$ cell infusion (data not shown).

Our studies focused on exploring the activity of purified $\mathrm{T}$ cell-containing DLI and results revealed that IL-15SA administration significantly enhanced the activity of DLI in murine lymphoma model. Safety and feasibility of DLI and an IL-15SA combination would be further investigated in the future clinical studies. We have recently begun studies in non-transplant lymphoma models, and preliminary data reveals that IL-15SA can increase antilymphoma activity of autologous $\mathrm{T}$ cell infusion in normal mice after lymphodepletion, suggesting that IL-15SA may play a role in the lymphoma/leukemia therapy.

Herein, we have demonstrated that once a week administration of IL-15SA could provide sustained immunological activity and anti-tumor activity in murine tumor models, murine mastocytoma and murine B cell lymphoma. Substantial anti-tumor activity of IL15SA has also been previously reported against multiple myeloma in syngeneic models [24]. This is likely due to the longer serum half-life of IL-15SA and its favorable pharmacokinetic profile compared to rhIL-15 [21]. The results of these studies support the weekly dosing regimen currently in various clinical trials for solid and hematological malignancies (Personal communication- Dr Wong, Altor Bioscience).

In summary, IL-15SA is a potent lymphoid growth factor and could be used as a powerful therapeutic for boosting the immune function in recipients of stem cell transplantation and adoptive $\mathrm{T}$ cell therapy without exacerbating GVHD. An evaluation of its clinical utility for stem cell transplantation and adoptive cellular therapies is warranted.

\section{MATERIALS AND METHODS}

\section{Mice and bone marrow transplant (BMT)}

Female C57BL/6 (B6, H-2K $\left.{ }^{\mathrm{b}}\right)$, Balb/c $\left(\mathrm{H}-2 \mathrm{~K}^{\mathrm{d}}\right)$, B6CBAF1 $\left(\mathrm{H}-2 \mathrm{~K}^{\mathrm{b} / \mathrm{k}}\right)$, CB6F1 $\left(\mathrm{H}-2 \mathrm{~K}^{\mathrm{b} / \mathrm{d}}\right)$ and B6D2F1 $\left(\mathrm{H} 2 \mathrm{~K}^{\mathrm{b} / \mathrm{d}}\right)$ mice were obtained from the Jackson Laboratory (Bar Harbor, ME). Mice used in BMT experiments were between 10--12 weeks of age. BMT protocols were approved by the Institutional Animal Care and Use Committee (IACUC) at Thomas Jefferson University.

Bone marrow (BM) cells were removed aseptically from femurs and tibias and T cells depleted (TCD) by incubation with anti-Thy 1.2 antibody for $30 \mathrm{~min}$ at $4{ }^{\circ} \mathrm{C}$, followed by incubation with Low-TOX-M rabbit complement (Cedarlane Laboratories, Hornby, Ontario, Canada) for 40 minutes at $37^{\circ} \mathrm{C}$, or alternatively via antiCD5 magnetic bead depletion (Miltenyi, Auburn, CA). Typical levels of contaminating $\mathrm{T}$ cells after complement depletion ranged from 0.2 to 0.5 percent of all bone marrow leukocytes.

Splenic T cells were obtained by positive selection with anti-CD5 antibodies conjugated to magnetic beads (Miltenyi, Auburn, CA). Cells $\left(5 \times 10^{6} \mathrm{BM}\right.$ cells with or without splenic $\mathrm{T}$ cells) were resuspended in Dulbecco Modified Eagle's Medium (DMEM) and transplanted by tail vein infusion ( $0.25 \mathrm{ml}$ total volume) into lethally irradiated recipients on day 0 . On day 0 prior to transplantation, recipients received 11 to 13 Gy total body irradiation (strain 
dependent) from a ${ }^{137} \mathrm{Cs}$ source as a split dose with a 3 hour interval between doses to reduce gastrointestinal toxicity. Mice were housed in sterilized micro-isolator cages and received normal chow and autoclaved hyper-chlorinated drinking water ( $\mathrm{pH} 3.0)$.

\section{Cell lines, antibodies, and cytokines}

P-815 (H-2d) cell line was obtained from ATCC (Manassas, VA). A20 (H-2d) murine lymphoma cell line, retrovirally transduced to express a triple fusion protein consisting of Herpes simplex virus thymidine kinase, enhanced green fluorescent protein (eGFP) and firefly luciferase (TGL), was kindly provided by Dr. Marcel van den Brink (Memorial Sloan Kettering Cancer Center, New York, NY). Cells were cultured in RPMI with 10\% FBS in atmosphere containing 5\% CO2.

Anti-murine CD16/CD32 FcR block (2.4G2) and all of the following fluorochrome-labeled antibodies against murine antigens were obtained from BD Pharmingen (San Diego, CA): H2Kd (SF1-1.1), CD3 (500A2), CD4 (RM45), CD8 (53-6.7), CD25 (PC61), CD44 (IM7), CD45R/ B220 (RA3-6B2), CD62L (MEL-14), NK1.1 (PK136), TNF- $\alpha$ (MP6-XT22), IFN- $\gamma$ (XMG1.2), NK2GD, isotype

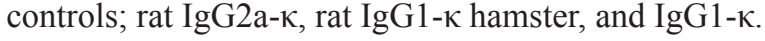

Cytokine complex IL-15SA (ALT-803) was kindly provided by Altor BioScience Corporation, Miramar, Florida. IL-15SA (ALT-803) was administered intraperitoneally, weekly at $1-2.5 \mu \mathrm{g} /$ day.

\section{Flow cytometry}

Single cell suspension of $10^{6}$ cells $/ 25 \mu \mathrm{L}$ was incubated at $4^{\circ} \mathrm{C}$ with $\mathrm{CD} 16 / \mathrm{CD} 32 \mathrm{FcR}$ block. Subsequently, cells were incubated at $4{ }^{\circ} \mathrm{C}$ with antibodies in a total volume of $50 \mu \mathrm{l}$. The stained cells were analyzed on a FACS Calibur flow cytometer (Becton Dickinson, San Jose, CA) with CellQuest software or LSRII cytometer (Becton Dickinson, San Jose, CA) with FlowJo software (Treestar, San Carlos, CA).

\section{Assessment of graft-versus-host-disease}

The severity of GVHD was assessed with a clinical GVHD scoring system as previously described [47]. Briefly, ear-punched animals in coded cages were individually scored every week using 5 clinical parameters based on a scale from 0 to 2: weight loss, posture, mobility, fur, and skin. A clinical GVHD index was generated by summation of the 5 criteria scores $(0-10)$. Survival was monitored daily. Animals with scores of at least 5 were considered moribund and were sacrificed.

\section{PMA-ionomycin stimulation and intracellular staining}

Splenocytes were incubated with PMA (20 ng/mL) and ionomycin $(1 \mu \mathrm{M})$ for 5 hours. Brefeldin A was added at a concentration of $10 \mu \mathrm{g} / \mathrm{mL}$ two hours following the addition of PMA and ionomycin. Cells were first stained with surface antibodies and then fixed and permeabilized with the BD Cytofix/Cytoperm Kit (BD Biosciences, San Diego, CA) and subsequently stained with intracellular antibodies.

\section{CFSE labeling}

Cells were labeled with carboxyfluorescein succinimidyl ester (CFSE) as previously described [48]. Briefly, splenocytes were incubated with CFSE at a final concentration of $2.5 \mu \mathrm{M}$ in $\mathrm{PBS}$ at $37^{\circ} \mathrm{C}$ for 20 minutes. Cells were then washed three times with PBS before intravenous injection.

\section{Statistics}

All values shown in graphs represent the mean \pm SEM. Survival data were analyzed using the MantelCox log-rank test. For all other analysis, nonparametric unpaired Mann-Whitney- $U$ test was used.

\section{Authors' contributions}

C.P.B performed the experiments and wrote the paper. C.T.S., M.M.P, C.B. and T.B-A. performed experiments. N.F. supervised the experiments. H.C.W., and E.K.J. wrote, and edited the paper. O.A. designed the experiments, analyzed the data, wrote the paper.

\section{ACKNOWLEDGMENTS}

C.P.B., T.B-A., C.T.S., M.M.P., C.B., N.F., and O.A. do not have any conflict of interest. H.C.W. and E.K.J. are employees and stockholders of Altor BioScience Corporation (Miramar, FL). This study is partially supported by a research grant from Altor BioScience Corporation.

\section{CONFLICTS OF INTEREST}

None.

\section{REFERENCES}

1. Cooper MA, Fehniger TA, Turner SC, Chen KS, Ghaheri BA, Ghayur T, Carson WE, Caligiuri MA. Human natural killer cells: a unique innate immunoregulatory role for the CD56(bright) subset. Blood. 2001; 97:3146-51.

2. Grabstein KH, Eisenman J, Shanebeck K, Rauch C, Srinivasan S, Fung V, Beers C, Richardson J, Schoenborn MA, Ahdieh M, Johnson L, Alderson MR, Watson JD, et al. Cloning of a $\mathrm{T}$ cell growth factor that interacts with the beta chain of the interleukin-2 receptor. Science. 1994; 264:965-8.

3. Giri JG, Kumaki S, Ahdieh M, Friend DJ, Loomis A, Shanebeck K, DuBose R, Cosman D, Park LS, 
Anderson DM. Identification and cloning of a novel IL-15 binding protein that is structurally related to the alpha chain of the IL-2 receptor. Embo J. 1995; 14:3654-63.

4. Prlic M, Blazar BR, Farrar MA, Jameson SC. In vivo survival and homeostatic proliferation of natural killer cells. J Exp Med. 2003; 197:967-76.

5. Carson WE, Fehniger TA, Haldar S, Eckhert K, Lindemann MJ, Lai CF, Croce CM, Baumann $\mathrm{H}$, Caligiuri MA. A potential role for interleukin-15 in the regulation of human natural killer cell survival. J Clin Invest. 1997; 99:937-43.

6. Evans R, Fuller JA, Christianson G, Krupke DM, Troutt AB. IL-15 mediates anti-tumor effects after cyclophosphamide injection of tumor-bearing mice and enhances adoptive immunotherapy: the potential role of NK cell subpopulations. Cell Immunol. 1997; 179:66-73.

7. Marks-Konczalik J, Dubois S, Losi JM, Sabzevari H, Yamada N, Feigenbaum L, Waldmann TA, Tagaya Y. IL2-induced activation-induced cell death is inhibited in IL-15 transgenic mice. Proc Natl Acad Sci U S A. 2000; 97:11445-50.

8. Katsanis E, Xu Z, Panoskaltsis-Mortari A, Weisdorf DJ, Widmer MB, Blazar BR. IL-15 administration following syngeneic bone marrow transplantation prolongs survival of lymphoma bearing mice. Transplantation. 1996; 62:872-5.

9. Judge AD, Zhang X, Fujii H, Surh CD, Sprent J. Interleukin 15 controls both proliferation and survival of a subset of memory-phenotype CD8(+) T cells. J Exp Med. 2002; 196:935-46.

10. Alpdogan O, Eng JM, Muriglan SJ, Willis LM, Hubbard VM, Tjoe KH, Terwey TH, Kochman A, van den Brink MR. Interleukin-15 enhances immune reconstitution after allogeneic bone marrow transplantation. Blood. 2005; 105:865-73. doi: 10.1182/blood-2003-09-3344.

11. Sauter CT, Bailey CP, Panis MM, Biswas CS, BudakAlpdogan T, Durham A, Flomenberg N, Alpdogan O. Interleukin-15 administration increases graft-versus-tumor activity in recipients of haploidentical hematopoietic SCT. Bone marrow transplantation. 2013; 48:1237-42. doi: 10.1038/bmt.2013.47.

12. Ward A, Anderson M, Craggs RI, Maltby J, Grahames C, Davies RA, Finch D, Pattison D, Oakes H, Mallinder PR. E. coli expression and purification of human and cynomolgus IL-15. Protein Expr Purif. 2009; 68:42-8.

13. Bessard A, Sole V, Bouchaud G, Quemener A, Jacques Y. High antitumor activity of RLI, an interleukin-15 (IL-15)IL-15 receptor alpha fusion protein, in metastatic melanoma and colorectal cancer. Mol Cancer Ther. 2009; 8:2736-45.

14. Ring AM, Lin JX, Feng D, Mitra S, Rickert M, Bowman GR, Pande VS, Li P, Moraga I, Spolski R, Ozkan E, Leonard WJ, Garcia KC. Mechanistic and structural insight into the functional dichotomy between IL-2 and IL-15. Nat Immunol. 2012; 13:1187-95. doi: 10.1038/ni.2449.
15. Stoklasek TA, Schluns KS, Lefrancois L. Combined IL15/IL-15Ralpha immunotherapy maximizes IL-15 activity in vivo. J Immunol. 2006; 177:6072-80.

16. Dubois S, Patel HJ, Zhang M, Waldmann TA, Muller JR. Preassociation of IL-15 with IL-15R alpha-IgG1-Fc enhances its activity on proliferation of $\mathrm{NK}$ and $\mathrm{CD} 8+/$ CD44high $\mathrm{T}$ cells and its antitumor action. J Immunol. 2008; 180:2099-106.

17. Epardaud M, Elpek KG, Rubinstein MP, Yonekura AR, Bellemare-Pelletier A, Bronson R, Hamerman JA, Goldrath AW, Turley SJ. Interleukin-15/interleukin-15R alpha complexes promote destruction of established tumors by reviving tumor-resident CD8+ T cells. Cancer Res. 2008; 68:2972-83. doi: 10.1158/0008-5472.CAN-08-0045.

18. Zhu X, Marcus WD, Xu W, Lee HI, Han K, Egan JO, Yovandich JL, Rhode PR, Wong HC. Novel human interleukin-15 agonists. J Immunol. 2009; 183:3598-607. doi: 10.4049/jimmunol.0901244.

19. Bergamaschi C, Rosati M, Jalah R, Valentin A, Kulkarni V, Alicea C, Zhang GM, Patel V, Felber BK, Pavlakis GN. Intracellular interaction of interleukin-15 with its receptor alpha during production leads to mutual stabilization and increased bioactivity. J Biol Chem. 2008; 283:4189-99.

20. Duitman EH, Orinska Z, Bulanova E, Paus R, BulfonePaus S. How a cytokine is chaperoned through the secretory pathway by complexing with its own receptor: lessons from interleukin-15 (IL-15)/IL-15 receptor alpha. Mol Cell Biol. 2008; 28:4851-61.

21. Han KP, Zhu X, Liu B, Jeng E, Kong L, Yovandich JL, Vyas VV, Marcus WD, Chavaillaz PA, Romero CA, Rhode PR, Wong HC. IL-15:IL-15 receptor alpha superagonist complex: high-level co-expression in recombinant mammalian cells, purification and characterization. Cytokine. 2011; 56:804-10. doi: 10.1016/j.cyto.2011.09.028.

22. Mortier E, Quemener A, Vusio P, Lorenzen I, Boublik Y, Grotzinger J, Plet A, Jacques Y. Soluble interleukin-15 receptor alpha (IL-15R alpha)-sushi as a selective and potent agonist of IL-15 action through IL-15R beta/gamma. Hyperagonist IL-15 x IL-15R alpha fusion proteins. J Biol Chem. 2006; 281:1612-9. doi: 10.1074/jbc.M508624200.

23. Rubinstein MP, Kovar M, Purton JF, Cho JH, Boyman O, Surh CD, Sprent J. Converting IL-15 to a superagonist by binding to soluble IL-15R \{alpha\}. Proc Natl Acad Sci U S A. 2006; 103:9166-71. doi: 10.1073/pnas.0600240103.

24. Xu W, Jones M, Liu B, Zhu X, Johnson CB, Edwards AC, Kong L, Jeng EK, Han K, Marcus WD, Rubinstein MP, Rhode PR, Wong HC. Efficacy and mechanism-of-action of a novel superagonist interleukin-15: interleukin-15 receptor $\mathrm{alphaSu} / \mathrm{Fc}$ fusion complex in syngeneic murine models of multiple myeloma. Cancer Res. 2013; 73:3075-86. doi: 10.1158/0008-5472.CAN-12-2357.

25. Alpdogan O, Muriglan SJ, Eng JM, Willis LM, Greenberg AS, Kappel BJ, van den Brink MR. IL-7 enhances peripheral $\mathrm{T}$ cell reconstitution after allogeneic 
hematopoietic stem cell transplantation. J Clin Invest. 2003; 112:1095-107. doi: 10.1172/JCI17865.

26. Alpdogan O, Muriglan SJ, Kappel BJ, Doubrovina E, Schmaltz C, Schiro R, Eng JM, Greenberg AS, Willis LM, Rotolo JA, O'Reilly RJ, van den Brink MR. Insulinlike growth factor-I enhances lymphoid and myeloid reconstitution after allogeneic bone marrow transplantation. Transplantation. 2003; 75:1977-83. doi: 10.1097/01. TP.0000070167.81584.A2.

27. Alpdogan O, Schmaltz C, Muriglan SJ, Kappel BJ, Perales MA, Rotolo JA, Halm JA, Rich BE, van den Brink MR. Administration of interleukin-7 after allogeneic bone marrow transplantation improves immune reconstitution without aggravating graft-versus-host disease. Blood. 2001; 98:2256-65.

28. Sauter CT, Bailey CP, Panis MM, Biswas CS, BudakAlpdogan T, Durham A, Flomenberg N, Alpdogan O. Interleukin-15 administration increases graft-versus-tumor activity in recipients of haploidentical hematopoietic SCT. Bone Marrow Transplant. 2013; 48:1237-42. doi: 10.1038/ bmt.2013.47.

29. Wong HC, Jeng EK, Rhode PR. The IL-15-based superagonist ALT-803 promotes the antigen-independent conversion of memory CD8 T cells into innate-like effector cells with antitumor activity. Oncoimmunology. 2013; 2: e26442. doi: 10.4161/onci.26442.

30. Kolb HJ, Mittermuller J, Clemm C, Holler E, Ledderose G, Brehm G, Heim M, Wilmanns W. Donor leukocyte transfusions for treatment of recurrent chronic myelogenous leukemia in marrow transplant patients. Blood. 1990; 76:2462-5.

31. Tomblyn M, Lazarus HM. Donor lymphocyte infusions: the long and winding road: how should it be traveled? Bone marrow transplantation. 2008; 42:569-79. doi: 10.1038/ bmt.2008.259.

32. Berger C, Berger M, Hackman RC, Gough M, Elliott C, Jensen MC, Riddell SR. Safety and immunologic effects of IL-15 administration in nonhuman primates. Blood. 2009; 114:2417-26. doi: blood-2008-12-189266.

33. Conlon KC, Lugli E, Welles HC, Rosenberg SA, Fojo AT, Morris JC, Fleisher TA, Dubois SP, Perera LP, Stewart DM, Goldman CK, Bryant BR, Decker JM, et al. Redistribution, hyperproliferation, activation of natural killer cells and CD8 $\mathrm{T}$ cells, and cytokine production during first-inhuman clinical trial of recombinant human interleukin-15 in patients with cancer. J Clin Oncol. 2015; 33:74-82. doi: 10.1200/JCO.2014.57.3329.

34. Bauer S, Groh V, Wu J, Steinle A, Phillips JH, Lanier LL, Spies T. Activation of NK cells and T cells by NKG2D, a receptor for stress-inducible MICA. Science. 1999; 285:727-9.

35. Coudert JD, Held W. The role of the NKG2D receptor for tumor immunity. Semin Cancer Biol. 2006; 16:333-43. doi: 10.1016/j.semcancer.2006.07.008.
36. Karimi MA, Bryson JL, Richman LP, Fesnak AD, Leichner TM, Satake A, Vonderheide RH, Raulet DH, Reshef R, Kambayashi T. NKG2D expression by CD8+ T-cells contributes to GVHD and GVT effects in a murine model of allogeneic HSCT. Blood. 2015; 125:3655-63. doi: 10.1182/blood-2015-02-629006.

37. Maccalli C, Scaramuzza S, Parmiani G. TNK cells (NKG2D+CD8+ or CD4+ T lymphocytes) in the control of human tumors. Cancer Immunol Immunother. 2009; 58:801-8. doi: 10.1007/s00262-008-0635-x.

38. Seay K, Church C, Zheng JH, Deneroff K, Ochsenbauer C, Kappes JC, Liu B, Jeng EK, Wong HC, Goldstein H. In Vivo Activation of Human NK Cells by Treatment with an Interleukin-15 Superagonist Potently Inhibits Acute In Vivo HIV-1 Infection in Humanized Mice. J Virol. 2015; 89:6264-74. doi: 10.1128/JVI.00563-15.

39. Ruggeri L, Capanni M, Urbani E, Perruccio K, Shlomchik WD, Tosti A, Posati S, Rogaia D, Frassoni F, Aversa F, Martelli MF, Velardi A. Effectiveness of donor natural killer cell alloreactivity in mismatched hematopoietic transplants. Science. 2002; 295:2097-100. doi: $10.1126 /$ science. 1068440 .

40. Collins RH Jr, Shpilberg O, Drobyski WR, Porter DL, Giralt S, Champlin R, Goodman SA, Wolff SN, Hu W, Verfaillie C, List A, Dalton W, Ognoskie N, et al. Donor leukocyte infusions in 140 patients with relapsed malignancy after allogeneic bone marrow transplantation. J Clin Oncol. 1997; 15:433-44.

41. Chang YJ, Huang XJ. Donor lymphocyte infusions for relapse after allogeneic transplantation: when, if and for whom? Blood Rev. 2013; 27:55-62. doi: 10.1016/j. blre.2012.11.002.

42. Inamoto Y, Fefer A, Sandmaier BM, Gooley TA, Warren EH, Petersdorf SH, Sanders JE, Storb RF, Appelbaum FR, Martin PJ, Flowers ME. A phase I/II study of chemotherapy followed by donor lymphocyte infusion plus interleukin-2 for relapsed acute leukemia after allogeneic hematopoietic cell transplantation. Biol Blood Marrow Transplant. 2011; 17:1308-15. doi: 10.1016/j.bbmt.2011.01.004.

43. Johnson BD, Truitt RL. Delayed infusion of immunocompetent donor cells after bone marrow transplantation breaks graft-host tolerance allows for persistent antileukemic reactivity without severe graftversus-host disease. Blood. 1995; 85:3302-12.

44. Billiau AD, Fevery S, Rutgeerts O, Landuyt W, Waer M. Crucial role of timing of donor lymphocyte infusion in generating dissociated graft-versus-host and graft-versusleukemia responses in mice receiving allogeneic bone marrow transplants. Blood. 2002; 100:1894-902. doi: 10.1182/blood-2002-02-0419.

45. Durakovic N, Radojcic V, Skarica M, Bezak KB, Powell JD, Fuchs EJ, Luznik L. Factors governing the activation of adoptively transferred donor $T$ cells infused after allogeneic bone marrow transplantation in the mouse. Blood. 2007; 109:4564-74. doi: 10.1182/blood-2006-09-048124. 
46. Mapara MY, Kim YM, Wang SP, Bronson R, Sachs DH, Sykes M. Donor lymphocyte infusions mediate superior graft-versus-leukemia effects in mixed compared to fully allogeneic chimeras: a critical role for host antigenpresenting cells. Blood. 2002; 100:1903-9. doi: 10.1182/ blood-2002-01-0023.

47. Cooke KR, Kobzik L, Martin TR, Brewer J, Delmonte J Jr, Crawford JM, Ferrara JL. An experimental model of idiopathic pneumonia syndrome after bone marrow transplantation: I. The roles of minor $\mathrm{H}$ antigens and endotoxin. Blood. 1996; 88:3230-9.

48. Lyons AB, Parish CR. Determination of lymphocyte division by flow cytometry. J Immunol Methods. 1994; 171:131-7. 